\title{
Application of Thwaites' Score in Central Nervous System Infection in an Immunocompetent Patient: Case Series
}

\author{
Mirna Marhami Iskandar ${ }^{1, *}$, Sotianingsih ${ }^{2}$, R.M. Al Kindi ${ }^{3}$ \\ ${ }^{1}$ Department of Neurology, Faculty of Medicine and Health Sciences, Universitas Jambi* \\ ${ }^{2}$ Department of Clinical Pathology, Faculty of Medicine and Health Sciences, Universitas Jambi \\ ${ }^{3}$ Faculty of Medicine and Health Sciences, Universitas Jambi \\ Email: mirna_marhami@unja.ac.id
}

\begin{abstract}
Patients with infection in the central nervous system can deteriorate rapidly, so an empirical approach needs to be performed promptly with relevant supporting data that can be produced as early as possible. Decision-making in such cases can use scoring systems such as Thwaites diagnostic score. However, this requires analysis of cerebrospinal fluid, and this is not a commonly performed workup among patients in Jambi. To illustrate the role of routine cerebrospinal fluid analysis, including how the Thwaites scoring system is implemented.

Patients who present with the clinical presentation of suspected intracranial infection undergo the lumbar puncture procedure, and other supporting diagnostic procedures were performed where applicable. Results are then summarized and Thwaites score is calculated. Three patients are presented in this case series, and the Thwaites score for two patients were below 4, indicating that tuberculous meningitis is more probable. The score for the third patient was +7 , which indicated that bacterial meningitis is more probable. Routine cerebrospinal fluid analysis should be performed as the minimum supporting diagnostic for patients with suspected central nervous system infection, unless contraindications are present. Scoring systems such as Thwaites' score can then be applied to begin the most appropriate empirical treatment as early as possible.
\end{abstract}

Keywords: cerebrospinal fluid analysis, Thwaites score, lumbar puncture, central nervous system infection.

\section{INTRODUCTION}

Infection of the central nervous system (CNS) contributes to a high morbidity and mortality burden in developing countries, including Indonesia. In Cipto Mangunkusumo Hospital, the central referral hospital of the country, there have been a steadily increasing incidence and mortality rate within the previous decade [1]. Survivors of CNS infection, especially immunecompromised patients, will continue to have relapses or sequels of complications during outpatient care [2]. The main therapeutic goal for a patient with central nervous system infection in an emergency setting is to reduce intracranial pressure, but this is only for the initial treatment. Further therapy varies greatly, depending on the diagnosis, and the success of this therapy depends on whether it is actually the definitive treatment for the main causal microorganism [3].
History-taking and clinical presentation remains the most important factors for the clinician to base his or her decision on what the most probable differential diagnoses are. However, variables, such as the immune status of a patient, is essential to narrow down the differentials even further. Evidence of immunodeficiency, e.g. the patient is proven to be HIV positive, can change the therapeutic direction significantly, i.e. opportunistic infections are considered $[3,4]$. Epidemiological data should also be taken into consideration, as the most probable causative agent may vary from region to region [4].

Patients with infection in the central nervous system can deteriorate rapidly, so empirical approach needs to be performed promptly $[5,6]$. Therefore, the purpose is to collect supporting data that yield early results, but are relevant to the diagnosis. Analysis of cerebrospinal fluid (CSF) currently remains one of the most significant initial supporting examinations for diagnosing intracranial infection. However, within certain regions of Indonesia, 
there have been several challenges in obtaining CSF, as the procedure of lumbar puncture may not always be possible, due to lack of kits, patient consent, among other things [7]. Many studies have already described the findings that can help determine the causal microorganism from routine CSF analysis, to differentiate from bacterial, viral, parasitic, or tuberculous infection of the meninges or the brain parenchyma. Furthermore, scoring systems can be used to determine the most probable aetiology. Empirical treatment can then be initiated, whereas a more definitive diagnosis may need more time, higher costs, or invasive procedures $[8,9]$.

Worldwide, tuberculosis (TB) is still the leading cause of death among other infections. Besides affecting the lungs, extrapulmonary TB can also cause mortality and morbidity, with CNS TB being the most lifethreatening form. As soon as the diagnosis is established, the management of CNS TB can be carried out, which comprises of anti-tuberculosis drugs and corticosteroids. However, concluding that the diagnosis is CNS TB can be challenging $[10,11]$.

The clinical presentation of CNS TB is largely nonspecific and variable, and can apply to other causes of meningitis or meningoencephalitis: headache, fever, and positive meningeal signs, with or without focal neurological deficits. Culture of Mycobacterium tuberculosis from CSF is still the gold standard, but the sensitivity is quite low. It also takes up to five weeks to reach the results; waiting for this result before beginning anti-TB therapy to a suspected CNS TB patient can prove fatal. Other laboratory tests or scoring systems based on routine laboratory results are proposed in several guidelines [11].

In 2002, Thwaites et al developed a scoring system based on clinical picture and laboratory values including CSF properties that can determine whether a meningitis presentation tends to be tuberculous [12]. The validity of this system has been proven by several large cohort studies, being proved to have a high sensitivity [13]. Imam et al published a study about the accuracy of the Thwaites' diagnostic score in retrospective cohort of meningitis patients, regarding cases that are suggestive of
TB meningitis, and reported that sensitivity is $97.5 \%$, specificity was $49.8 \%$, positive predictive value was $63.4 \%$ and negative predictive value was $93.9 \%$. When calculated in determining bacterial vs. tuberculous meningitis, the study reported excellent sensitivity (93.9\%) and specificity (96\%). Routine analysis of CSF properties would be adequate for this scoring system, i.e. excluding specific reagents, culture, or staining.

Lumbar puncture (LP) and routine CSF analysis, are tests that are not commonly performed among patients with suspected CNS infection in Jambi. Neuroimaging are more widely known and accepted to be performed on almost patients; while useful in determining several key characteristics of central nervous system infection, radiological findings do not add much weight in eliminating differential diagnoses. This paper aims to illustrate how routine CSF analysis and other accessible and affordable supporting examinations, including calculation of Thwaites score, are important in helping with establishing a diagnosis.

\section{METHOD}

Subjects are collected by consecutive sampling, from March to October 2020. Inclusion criteria are adult patients (aged 18 years or older), from the outpatient neurology clinic or the inpatient wards, in hospitals in Jambi, presenting with clinical picture of CNS infection, including-but not limited to-acute or subacute headache, paresis or lesions of the cranial nerves, seizures, and other neurological deficits. LP is performed unless contraindicated. Blood tests are also performed. For the laboratory tests, components included in calculating Thwaites score are particularly focused on, i.e. serum white blood cell (WBC) count, CSF WBC count, and percentage of neutrophils from the CSF WBC count.

\section{RESULTS}

Three patients are presented in this paper: a 28-yearold female, an 18-year-old male, and a 19-year-old female. The patients presented with the typical clinical presentations of CNS infection, with slight difference. The demographic data and the clinical picture can be further observed in Table 1

Table 1. Demographic data and clinical picture.

\begin{tabular}{|c|c|c|c|}
\hline Variables & Patient 1 & Patient 2 & Patient 3 \\
\hline \multicolumn{4}{|l|}{ Demographics } \\
\hline Age (years) & 28 & 18 & 19 \\
\hline Sex & Female & Male & Female \\
\hline \multicolumn{4}{|l|}{ Neurologic status at initial presentation } \\
\hline Glasgow Coma Score & 10 & 13 & 11 \\
\hline Pupils & Reactive & Reactive & Reactive \\
\hline Cranial nerves paresis/lesions & + & - & - \\
\hline Lateralization based on motor strength & - & + & - \\
\hline Physiological reflexes & normal & normal & Normal \\
\hline Pathological reflexes & - & + & - \\
\hline
\end{tabular}




\begin{tabular}{|c|c|c|c|c|}
\hline & $\begin{array}{r}\text { Sensorium } \\
\text { Autonomic function disturbance } \\
\end{array}$ & $\begin{array}{c}\text { normal } \\
-\end{array}$ & $\begin{array}{c}\text { normal } \\
-\end{array}$ & $\begin{array}{c}\text { Normal } \\
-\end{array}$ \\
\hline \multicolumn{5}{|l|}{ Clinical Presentation Summary } \\
\hline & High Fever & + & + & + \\
\hline & Days of illness at admission & 7 & 9 & 2 \\
\hline & Duration of hospital stay (days) & 16 & 13 & 9 \\
\hline & Headache & + & - & + \\
\hline & Seizure & + & - & + \\
\hline & Altered consciousness & + & + & + \\
\hline & Skin rash & - & + & - \\
\hline & Meningeal sign & + & + & + \\
\hline & Myalgia & + & - & + \\
\hline & Focal neurological sign & + & + & - \\
\hline & Cognitive impairment & - & + & - \\
\hline & Hepatosplenomegaly & - & + & - \\
\hline & Lymphadenopathy & - & - & - \\
\hline
\end{tabular}

The laboratory results of the subjects can be seen in Table 2 .

Table 2. Serum and CSF results

\begin{tabular}{|c|c|c|c|c|}
\hline \multicolumn{2}{|c|}{ Laboratory Investigation } & Patient 1 & Patient 2 & Patient 3 \\
\hline \multicolumn{5}{|l|}{ Blood/Serum } \\
\hline & Hemoglobin $(\mathrm{g} / \mathrm{dL})$ & 10.8 & 7.2 & 10.0 \\
\hline & Hematocrit (\%) & 32.2 & 21.1 & 30.0 \\
\hline & $\mathrm{WBC}($ cells $/ \mu \mathrm{L})$ & 12,100 & 3,890 & 17,100 \\
\hline & Platelet (counts $/ \mu \mathrm{L}$ ) & 172,000 & 127,000 & 152,000 \\
\hline & Alanine transaminase (IU/L) & N/A & 66 & N/A \\
\hline & Aspartate transaminase (IU/L) & N/A & 52 & N/A \\
\hline & Urea $(\mathrm{mg} / \mathrm{dL})$ & 18 & 21 & 16.3 \\
\hline & Creatinine $(\mathrm{mg} / \mathrm{dL})$ & 0.7 & 0.9 & 0.7 \\
\hline & Glucose (mg/dL) & 131 & 127 & 122 \\
\hline & HIV & - & - & - \\
\hline \multicolumn{5}{|l|}{$\mathrm{CSF}$} \\
\hline & Colour & & None & \\
\hline & Clarity & & Clear & \\
\hline & Sedimen & & Negative & \\
\hline & Total cell count (cells/mL) & 450 & 1 & 100 \\
\hline & Mononuclear cell proportion (\%) & 43 & 98 & 97 \\
\hline & Polymorphonuclear cell proportion (\%) & 57 & 2 & 3 \\
\hline & Protein $(\mathrm{mg} / \mathrm{dL})$ & 1100 & 30 & 30 \\
\hline & Glucose $(\mathrm{mg} / \mathrm{dL})$ & Low & 55 & 100 \\
\hline & $\mathrm{CSF} /$ serum glucose ratio & & $55 / 127$ & $100 / 122$ \\
\hline & Chloride $(\mathrm{Cl})-\mathrm{mEq} / \mathrm{L}$ & 108 & 109.12 & 109.6 \\
\hline & Nonne & - & - & - \\
\hline & Pandy & - & - & - \\
\hline
\end{tabular}

Based on the data above, the Thwaites score can presented in the following table: be calculated for these patients, as

Table 3. Scoring of the patients based on Thwaites' Diagnostic Score ${ }^{16}$

\begin{tabular}{|c|c|c|c|c|}
\hline Parameters & Score & Patient 1 & Patient 2 & Patient 3 \\
\hline \multicolumn{5}{|l|}{ Age, years } \\
\hline$\geq 35$ & 2 & & & \\
\hline$<35$ & 0 & 0 & 0 & 0 \\
\hline \multicolumn{5}{|l|}{ Blood WBC, $10^{3} / \mathrm{ml}$} \\
\hline$\geq 15,000$ & 4 & & & \\
\hline$<15,000$ & 0 & 0 & 0 & 4 \\
\hline \multicolumn{5}{|l|}{ History of illness, days } \\
\hline$\geq 6$ & -5 & -5 & -5 & \\
\hline$<6$ & 0 & & & 0 \\
\hline
\end{tabular}


CSF total WBC, $10^{3} / \mathrm{ml}$

$\geq 900 \quad 3$

$<900 \quad 0$

0

CSF\% neutrophils

$\geq 75 \quad 4$

0

0

0

Total -2

Sunbul, M., Atilla, A., Esen, S., Eroglu, C., \& Leblebicioglu, H. (2005). Thwaites' diagnostic scoring and the prediction of tuberculous meningitis. Medical Principles and Practice, 14(3), 151-154.

Radiological data were also taken from the patients; plain chest radiographs did not show pulmonary $\mathrm{TB}$ in all three patients. Non-contrast enhanced cranial CT-scans of Patients 1 and 2 show some extent of diffuse oedema of the brain parenchyme; Patient 3 showed unremarkable findings.

As defined by this scoring system, patients with score $\leq 4$ are classified as having tuberculous meningitis while those with scores $>4$ are classified as having a version of bacterial meningitis. Therefore, it is shown on the table above that Patients 1 and 2 can be determined as having TB meningitis, whereas Patient 3 may be classified as having a version of bacterial meningitis. The therapy administered were therefore planned as appropriate: patients 1 and 2 received anti-TB drugs, and patient 3 received empirical broad-spectrum antibiotics at an intracranial dose.

\section{CONCLUSION}

The rapid deterioration of a central nervous system infection warrants early treatment against the etiology. Aside from clinical presentation, CSF analysis and routine laboratory values are essential for the neurologist to decide what empirical antimicrobial treatment that needs to begin promptly. Therefore, in the absence of absolute contraindication, performance of lumbar puncture should be performed in all patients with the clinical picture of CNS infection. Collaborative efforts need to be made with local laboratories and medical equipment stores and facilities to ensure that CSF analysis is a routine, affordable, and accessible laboratory examination.

\section{REFERENCES}

[1] Mawuntu A, Imran D, Jannis J dan Prihartono J. Angka Kematian Pasien AIDS dengan Infeksi Oportunistik Otak di RSCM tahun 2007 - 2010. Neurona; 20Christensen ASH, Roed C, Omland LH, dkk. Long-Term Mortality in Patients with Tuberculous Meningitis: A Danish Nationwide Cohort Study. PLoS ONE 6(11): e27900

[2] Imran D. Infeksi Tuberkulosis pada Susunan Saraf Pusat. In: Aninditha T, Wiratman W. Buku Ajar Neurologi. ch. 14. Jakarta: Departemen
Neurologi Fakultas Kedokteran Universitas Indonesia; 2017.

[3] Imran D dan Estiasari R. Modul NeuroAIDS 2011. Departemen Neurologi Fakultas Kedokteran Universitas Indonesia-Rumah Sakit Cipto Mangunkusmo. Jakarta; 2011

[4] Marchiori EP. Lino AM. Marchado LR. Pedalini LM. Boulos M. Scaff M. Neuroinfection survey at neurological ward in a Brazilian tertiary teaching hospital. CLINICS 2011;66(6):10211028

[5] Imran, D., Estiasari, R., Maharani, K., Sucipto, Lestari, D. C., Yunus, R. E., ... Van Crevel, R. (2018). Presentation, etiology, and outcome of brain infections in an Indonesian hospital: A cohort study. Neurology: Clinical Practice, 8(5), 379-388.

[6] Imran, D., Satiti, S., Sugianto, P., Estiasari, R., Maharani, K., Pangeran, D., ... \& van Crevel, R. (2019). Barriers to diagnosis and management of CNS infections in Indonesia. Neurology, 92(2), 104-106.

[7] Kurien, R., Sudarsanam, T. D., Samantha, S., \& Thomas, K. (2013). Tuberculous meningitis: A comparison of scoring systems for diagnosis. Oman Medical Journal, 28(3), 163166.

[8] Lee, S. A., Kim, S. W., Chang, H. H., Jung, H., Kim, Y., Hwang, S., ... Lee, J. M. (2018). A new scoring system for the differential diagnosis between tuberculous meningitis and viral meningitis. Journal of Korean Medical Science, 33(31).

[9] Thwaites G, Chau TT, Mai TH, dkk. Tuberculous meningitis. J Neurol Neurosurg Psychiatry 2000;68:289-299

[10] Misra UK, Kalita J, Srivastava M and Mandal SK. Prognosis of tuberculous meningitis: a multivariate analysis. J Neurol Sci 1996; 137: 57-61.

[11] Thwaites, G. E., Chau, T. T. H., Stepniewska, K., Phu, N. H., Chuong, L. V., Sinh, D. X., ... \& Farrar, J. J. (2002). Diagnosis of adult tuberculous meningitis by use of clinical and 
laboratory features. The Lancet, 360(9342), 1287-1292.

[12] Sulaiman, T., Medi, S., Erdem, H., Senbayrak, S., Ozturk-Engin, D., Inan, A., ... Hasbun, R. (2020). The diagnostic utility of the "Thwaites' system" and "lancet consensus scoring system" in tuberculous vs. non-tuberculous subacute and chronic meningitis: multicenter analysis of 395 adult patients. BMC Infectious Diseases, 20(1). 